Received : May 27, 2021

Accepted : August 16, 2021

Published : October 13, 2021
Homepage: http://trj.stptrisakti.ac.id/index.php/trj/index DOI: https://doi.org/10.30647/trj.v5i2.121

Tourism Research Journal

E-ISSN: 2598-9839

2021, Vol. 5 No. 2

\title{
Dark Tourism Opportunities and Challenges: A case study from Lapindo Mud Disaster
}

\author{
Katerina Bataha*, Silma Nuril Jannah, Faizzatun Nazira \\ Public Administration Study Program UPN Veteran East Java \\ *Katerina.bataha.adneg@upnjatim.ac.id
}

\begin{abstract}
The purpose of this article is to analyze the opportunities and challenges of the potential dark tourism of Lapindo Mud, as well as to find out the practice of Lapindo Mud dark tourism because of the many irregularities that the authors found when conducting research. The methodology used is a qualitative method with a case study approach. In-depth interviews with Lapindo mud victims, the Lapindo Mud Control Center observation, and documentation. The Opportunity of Lapindo Mud dark tourism is the tourist motivation for visiting Lapindo Mud is not to admire the natural beauty and take a vacation, but there is a spiritual and sympathetic sense of tourists interspersed with pain and even anger towards tragic stories caused by nature or human crimes to be unique. Some facts make challenges for this dark tourism; namely, management is carried out spontaneously or without planning. The focus of this study is indeed narrow, but the findings provide theoretical and practical insights into the conceptualization of dark tourism by analyzing opportunities and challenges related to the potential of dark tourism in Lapindo Mud. Thus, the understanding of this phenomenon can be improved and can be used to add knowledge and reference material for further research.
\end{abstract}

Keywords: Dark Tourism, Lapindo Mud, Tourist Motivation, Opportunities, Challenges 
Dark Tourism Opportunities and Challenges: A case study from Lapindo Mud Disaster

\section{A. Introduction}

Indonesia is a country with the highest disaster threat. The various, disasters occurred in Indonesia such as tsunamis, earthquakes, floods, volcanic eruptions, and others. One of the disasters that are still being discussed by the public is the Lapindo Mud. This case can be said to be unfinished because the responsibility of the government, both the central and local governments, for this incident has not been deemed effective for the victims. Many victims have not received compensation for the events they have experienced (Daulay, 2010).

The Lapindo Mud Disaster is located in Ketapang Village, Tanggulangin District, Sidoarjo Regency, East Java Province. The mud disaster that occurred began with the release of hot gas and mud from the former oil drilling owned by PT. Lapindo Brantas at Porong Sidoarjo (Daulay, 2019). The central government manipulated the timing of the incident because after the incident, there was an intermittent earthquake in Yogyakarta, so to avoid public misunderstandings and public opinion, the current President at that time (Fajerial, 2014).

The trigger of the Lapindo Mud is still being debated (Riski, 2013). Two conjectures that triggered the eruption according to the Sidoarjo Mud Management Agency in 2013, namely 1) an underground explosion was carried out from the Banjarpanji 1 exploration, and a high-pressure zone migrated through the Watukosek fault zone to the southeast-southwest direction. It was reactivated by increased tectonic activity and earthquakes. Therefore, the trigger of this first hypothesis was caused by a technical error or an accident at the oil drilling company by PT. Lapindo Brantas; 2) The second hypothesis states that the trigger comes from a natural event in another place, namely the Yogyakarta earthquake on May 27, 2006 (Farida, 2013). However, Davies and other geologists denied this and mentioned that drilling the well caused the mudflow. This eruption resulted in a unique development. This is because the mudflow widened in five years, not more than 10,000 years. Therefore, society has seen the growth of debris flow in a short time. This incident is unique and has never happened in the earth's history (Dewan, 2011).

Tourism originating from disasters and horrific events is the concept of dark tourism. Although this concept has been around for a long time, it is still rarely used in Indonesia. In general, tourism presents beauty and joy. But, dark tourism provides the opposite condition, namely by traveling to locations with stories of death, pain, suffering, and heartbreak. In general, tourist attractions are deliberately created for fun, but the Lapindo Mud dark tourism was different. The Lapindo Mud was built on the initiative of the community itself and the desire to rise from the downturn after the disaster occurred. So, tourist's motivation to visit Lapindo Mud is not to admire the natural beauty and recreation, but because of their particular interest such as the curiosity from tourists because of the origin of the Lapindo mud which emits hot mud so that it takes a lot of lives and buildings are submerged in mud. 
After the Lapindo Mud disaster circulated on various mass media and electronic media, many internet citizens also responded to it on their social media, making many people curious about this place. People and victims eventually used this situation to make tourist destinations by utilizing the Lapindo Mud embankments (Andriani, 2011). Not only that, many researchers, scientists, and journalists also came to seek information and interview the Lapindo Mud tourism managers who were victims of the Lapindo Mud. By seeing enthusiastic tourists who visit and see the Lapindo Mud dark tourism, people are optimistic that Lapindo Mud can provide benefits for them. The Lapindo Mud is not suitable for use as a tourist destination because it comes from a tragic event and is a dangerous area. However, this is precisely what makes Lapindo Mud a unique tourism opportunity.

The above reality led the authors to find that the Lapindo Mud disaster can develop into a tourist attraction. By looking at and studying the history of the Lapindo Mud disaster, Lapindo Mud can become dark tourism because the Lapindo Mud is an event that becomes a tragedy and a terrible story. In addition, tourists also visit out of curiosity about why did this happen? Can we prevent a situation like this? Who will bear the consequences for this incident? In this study, researchers will discuss the potential and challenges of dark tourism in Lapindo Mud, because analyzing the potential and challenges can contribute to the development of dark tourism in Lapindo Mud.

\section{B. Literature Review}

The focus of this research is the challenges and opportunities of dark tourism, in this case, the Lapindo Mud. Talking about opportunities and challenges, what will be discussed is the opportunity to develop the Lapindo Mud disaster tourism object into a tourist attraction that brings economic value and what challenges weaken the development of Lapindo Mud dark tourism. Dark tourism is an interesting tourist phenomenon to be discussed and studied further because it has a different concept from other destinations where natural disasters become a tourist attraction. Why disaster can be a tourist attraction? According to (Muktaf, 2017), this is closely related to the high emotional impact of someone visits a disaster site. Tourists become attracted to visit the site because of the "high emotional impact" associated with death, disaster, and the like so that they get a deeply emotional experience.

John Lennon and Malcolm Foley introduced dark tourism through their book, "Dark Tourism: The Attraction of Death and Disaster (White, Leanne; Frew, 2013). Initially, dark tourism was only related to death, fighting, and disasters. However, developments in the world of education, activities or behavior, and things that some people find strange, such as mysterious things, can be related to dark tourism (Jamin et al., 2020). 
Meanwhile, (Seaton, 1996) on (Dirgantara, 2013) created a new term called "Tana Tourism", which is a complete or partial, concrete, and symbolic motivation for death). That dark tourism is an adventure into the history of tragedies, tragic stories or experiences, heartbreaking human deaths, and activities that aim to improve the memory of events and their victims. Thus, That dark tourism is a behavioral phenomenon determined by tourist motives instead of specific characteristics of a tourist attraction.

Dark tourism is an educational tour that makes events that bring destruction, death, and life again as a tourist attraction. The victim's testimony, as well as the location of the incident, are authentic things to pay attention to. Direct experience when seeing a dark tourism site will provide a strong emotional experience because you can see and feel it, giving rise to empathy and life lessons in the future(Natalija Minić, 2012). The emotional impact of dark tourism is more pronounced than studying disasters in a museum. According to Farmaki (2013) appear in a particular article in the International Journal of Science of cultural and historical heritage, the paper defines dark tourism as presenting goods containing actual deaths and disasters consumed by tourists.

This trip is a modification of the description of death and creepy tales. Essentially, dark tourism exists for centuries such as the Roman Colosseum Games or the so-called "Gladiator's Battle", it shows the death and suffering of the victims and is presented as an exciting and scary image. Although this concept has been around for a long time, it is still rarely used in Indonesia. The form of dark tourism is different from natural tourism in general, which illustrates beauty and joy. Dark tourism provides the opposite condition, namely by traveling to locations with stories of death, pain, suffering, and heartbreak. Based on Government Regulation Number 50 of 2011 concerning the National Tourism Development Master Plan 2010-2025, dark tourism refers to commemorative tourism or historical tourism (Kementrian Pariwisata, 2019).

\section{Research Methodology}

A qualitative method with a case study approach was used in this research and writing. Researchers use the case study approach to examine plans, activities, processes, events, or a group of individuals (Cresswell, 2014). By using a case study approach, this research was able to reveal specific, unique, and detailed things and present clear findings on the opportunities and challenges of Lapindo Mud dark tourism. This research was conducted at the Lapindo Mud disaster location in Ketapang Village, Tanggulangin District, Sidoarjo Regency, East Java Province, Indonesia.

Data collection was carried out Data collection in the journal have 3 questions: (1) Related to the financial management of visitors in terms of tariffs that change every tourist; (2) Opinions about tourist take a picture in the region of Lapindo Mud; (3) Question about liberties and equity tourism at the planning 
development and management process in Lapindo Mud, was carried out through: a) interviews with relevant village hall employees, Mr. Legiman, Mr. Soeharto, Mr. Suwaji, Mr. Usmanias victims of the Lapindo Mudflow incident while also participating in fighting for their rights to obtain justice, and also participated in the process planning, development, and management of Lapindo Mud tourism; b) field observations by visiting the Lapindo Mud tourism, seeing the existing situation and making contributions to the victims of the Lapindo Mudflow who are the author's resource persons; c) written documentation, such as notes in journals, and social media

\section{Result and Discussion}

According to Mr. Legiman, Mr. Soeharto, Mr. Suwaji, Mr. Isman as witnesses, victims, and our informants, the Lapindo Mud incident occurred 15 years ago on Tuesday, May 23, 2006, 00.30 WIB. This tourism potential can be called dark tourism because this disaster has elements of tragedy, tales, heartbreaking and terrible stories. Lapindo Mud dark tourism can be called a tourist destination because the activities carried out at the site have presented various influences to the community. From the author's observations during the research, Lapindo Mud victims formed an association called the Lapindo Mud tourism association, which aims to create Lapindo Mud dark tourism since 2015.

\section{Opportunities of Dark Tourism in Lapindo Mud}

From the concept of dark tourism, Lapindo Mud is an event that has become a tragedy and a terrible story. Based on the author's interview results with Mr. Legiman, Mr. Soeharto, Mr. Usmani, and Mr. Suwaji, there were pros and cons from the local community with P.T Lapindo regarding licensing and land use. Here is the interview from Mr. Legiman and Mr. Soharto as a motorcycle taxi and Lapindo mud's victim regarding the origin of the Lapindo land's liberation. they are both victims at the motorcycle now taxi drivers for tourists who come to visit in Lapindo Mud

Mr. Legiman Said "At that time, it coincided with the election of the village head (pilkada) which contained a political contract in it. When the chosen candidate is elected, the candidate asks for political funds from PT. Lapindo. This is used by PT. Lapindo to request land acquisition. Initially, PT. Lapindo has applied for a permit for the land to be used as an animal feed factory. To gain the trust of the local community, PT. Lapindo organizes cattle processions and eats together. Big cows came from Bali. But actually, this is just the reason why PT. Lapindo. A kind of alibi to trick the local people. Investigate by investigating, the land is used as a place to drill for natural gas".

During the construction period, there was an accident, namely an earth pipe leak. Little by little, the leak produced boiling mud that began to destroy many houses, buildings and schools, factories, and land for farming, such as rice fields and surrounding fields. The total of the Lapindo Mudflow's victims on the map 
(whose houses have been buried) and the outside of the map (which have not been buried) are 90,000 people. This is burst eventually built a puddle. It is like a lake that destroyed various sources of livelihood for the local people. At that time submerged eight villages, namely, Kalitengah village, Basuki village, Pejarakan village, Siring village, Kedungbendo village, Jatirejo village and locations around Tanggul Angin Sejahtera Housing Sidoarjo (Gupta, 2016).

In essence, a tourist comes to a tourist destination in search of beauty, vacation, and pleasure. However, unlike other tourist attractions in Lapindo Mud, the tourists who have visited and seen firsthand feel sadness and sympathy for disaster victims whose families cannot be saved. They also offer prayers for the victims to be calm by God's side. His sympathy was about to emerge beforehand because most tourists already know the accident in Lapindo Mudflow. Not only that, but they also took a tourist motorcycle taxi as a form of concern for the victims. Therefore, tourism occurs as a result of a tragedy, which took so that Lapindo mud deserves to have the potential for dark tourism. Because that dark tourism can make tourists change their behavior more.

The concept of dark tourism has a very good opportunity to be developed (Kunwar \& Karki, 2019). There are still many people out there who don't know the dark side of the Lapindo mud disaster which attracted the attention of foreign researchers who revealed that the mud containing gas could be sold, but the residents affected by the disaster could not take the mud because it no longer belonged to them. the residents but belongs to PT. Lapindo Brantas if the residents take the mud to sell then they will face the law. The connection between the object visited and the spiritual traveler interspersed with pain and anger towards tragic events caused by nature or human evil is its influence and uniqueness (Rahmawati \& Reni, 2019). On the other hand, dark tourism is also considered to tempt the conscience of the informants Mr. Legiman, Mr. Soeharto, Mr. Suwaji, Mr. Isman believe that half of the children must be cared for and maintained.

Currently, at the Lapindo Mud location, there are 110 statues placed at 21 points of mud retaining embankments, created by artist Dadang Christanto. The statues are lined up with their hands raised upwards while holding the rubbish of household utensils covered with mud. The meaning of this statue is the victims of Lapindo Mud, who used to have a calm and social life but is now different. While the hands upwards symbolize that they are grieving (Syaraffah, 2014). 


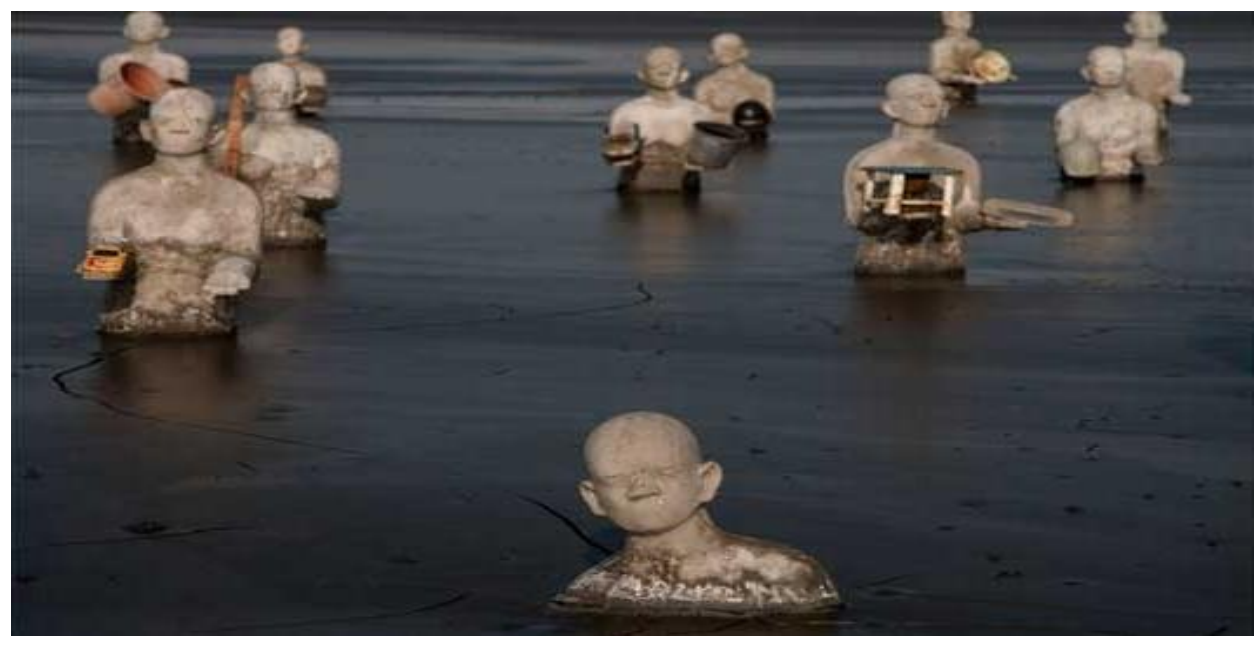

Figure 1. An Installation Statue of The Artist Dadang Christanto Source: Syaraffah (2014)

Although it is not a beautiful sight and there are no objects for rides to play with. Foreigners also participated in the visit. Most of them went to see the Lapindo Mud area out of curiosity or had a vacation at another resort that passed Jalan Raya Porong. Tourists who visit are usually in groups, even on holidays. The main road is blocked because many people want to observe the location of the Lapindo mudslide itself. In terms of tourist attraction, Lapindo Mud has strengths that are compatible with the theme of dark tourism because it is associated with tragedy and disaster.

The cultural aspect is also obtained from spiritual strength and emotional ties because it is seen from the tourists who visit the location that they pray and visit the graves of their relatives. The reason is, the Lapindo Mud tourist destination is on the grave of their family, who had died due to being drowned by the Lapindo Mud when a tragic event struck their place of residence. Even though the Lapindo Mud embankment has been used as a destination at this time, they can still find out their family's graves because the victims have placed special markers on the area (Restanto \& Listiyani, 2013). When interviewing Mr. Soeharto as a victim of the Lapindo Mud, he admitted that he was sad when delivering tourists who took selfies. The following is the narrative of Mr. Soeharto.

"Sometimes I feel sad, when I send visitors who come, take photos and have fun, because the land they step on is the place where many people died, including my family, even this place is often used as pre-wedding photos and events. picnic like that. It doesn't matter actually. But thankfully there are not a few even many visitors who come to pray together, and Alhamdulillah, the tolerance is high here, so anyone who uses this custom is welcome according to their respective beliefs".

What Mr. Soeharto means is that tourists' emotional feelings shape their morale. The activities they carry out and their attitudes at the location impact or 
influence individuals, other tourists, and victims. There is the figure of the event and theatrical action of the Lapindo Mud's victims.

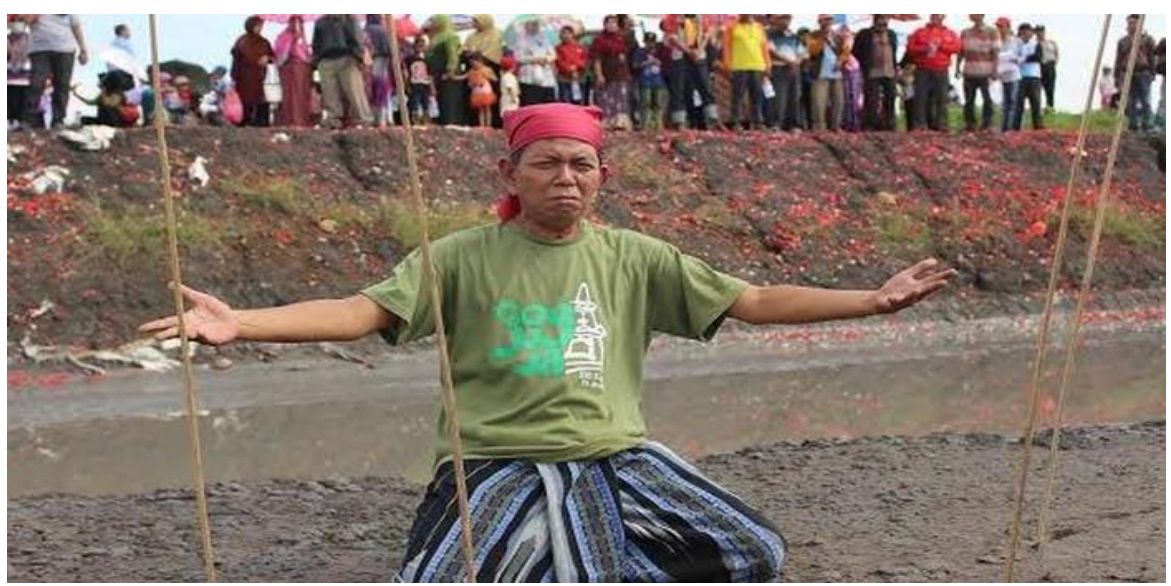

Figure 2. Flower-Sowing Event And Theatrical Action of the Lapindo Mud's Victims.

Source: Suparno (2016)

On the other hand, the opportunity of dark tourism in Lapindo Mud also affects the economic aspect, which provides considerable benefits such as opening new livelihoods. So that this can be used by people who depend their lives on Lapindo Mud, they can offer services such as motorcycle taxis, guides, parking attendants, photographers. In addition, they can also be sellers of snacks and drinks for tourists who come considering the Lapindo Mud disaster tourism has a hot temperature.

\section{Challenge of Dark Tourism in Lapindo Mud}

Behind the great opportunity of Lapindo Mud dark tourism, some facts make it a challenge for Lapindo Mud dark tourism. In a tourist destination, of course, some managers are responsible for managing tourism. The typical problem in tourism studies is usually when there is a dispute between actors in tourist destinations' management even though the place has already been established (Kriswibowo, 2018). Lapindo Mud dark tourism does not have a clear authority and there is no coordination between managers. Moreover, the existence of communities or external thugs who damage tourism destination management so that the management of Lapindo Mud is very messy because it handles tourists spontaneously, without any planning.

Tourism management should collaborate between people, organizations, and the government so that its goals are achieved. Not only related to cooperation, but also fully responsible for Lapindo Mud dark tourism management practice. Although it is known by the Sidoarjo Mud Control Center, the implementation of tourism in Lapindo Mud has not received permission from Sidoarjo Mud Control 
Dark Tourism Opportunities and Challenges: A case study from Lapindo Mud Disaster

Center, especially the authorities related to the disaster are the landowners, namely PT. Lapindo Brantas. Sidoarjo Mud Control Center did inform PT. Lapindo Brantas has tourism on their land and PT. Lapindo did not give a warning, but the people who make the area a tourist destination still did not have a permit from PT. Lapindo Brantas. Meanwhile, if you want to run tourism, some policies must be implemented by the association, as regulated in the Tourism Legislation no. 10 of 2009 in Article 15.

"As referred to in Article 14, a tourism entrepreneur must first register his business with the government or regional government to carry out a tourism business."

In this case, the Lapindo Mud tourism management has not registered and does not have an official permit, either from the Sidoarjo Regional Government or PT. Lapindo Brantas. Thus, the Lapindo Mud dark tourism will impact losses for tourists because if tourists get accidents or unwanted risk, there will be no responsible parties. Regarding entrance tickets, tourists there are charged different fees for each visitor. There are also no prices listed along the tour. But they bring the price if they make themselves, then they offer it to tourists. Here the statement was conveyed by Mr. Usmani.

'When you entered the first portal below, we didn't know because we didn't coordinate with them. They were thugs acting on behalf of Lapindo Mud tourism as if they were charging an entrance ticket, even though they had nothing to do with the victims. If the victims who were in the posts were all motorcycle taxis. We offer motorcycle taxi services as well as a tour guide. For the people of Sidoarjo and its surroundings who visit the Lapindo Mud, they are charged IDR 5,000, while tourists from outside the city are charged IDR 10,000. In the Lapindo Mud area, several motorcycle taxis have been provided for people who want to see firsthand and go around the Lapindo Mud area at a rate of IDR 30,000 per motorbike. For visitors using private vehicles, a rate of IDR 25,000 per motor is charged. Then, for visitors who want to know about the history of the Lapindo Mud incident, we sell the tapes for IDR 10,000 per cassette. But we don't insist on buying it, if it is bought, Alhamdulillah, if not, it doesn't matter, we will still tell it honestly, but the results are divided equally with the other victims ".

In addition, although the access to Lapindo Mud is easy to reach, it is close to the city center of Sidoarjo and is the main route to the city of Malang and one of the routes to the island of Bali. Meanwhile, access to the Lapindo Mud center is of inferior quality because the center of the eruption in the form of a mud embankment is still built of sand. When the dry season arrives, the road will crack become dusty. In contrast, when the rainy season falls, the road will be slippery and muddy. Therefore, tourists who explore Lapindo Mud become obstructed and uncomfortable (Abdillah \& Suryawan, 2019). 


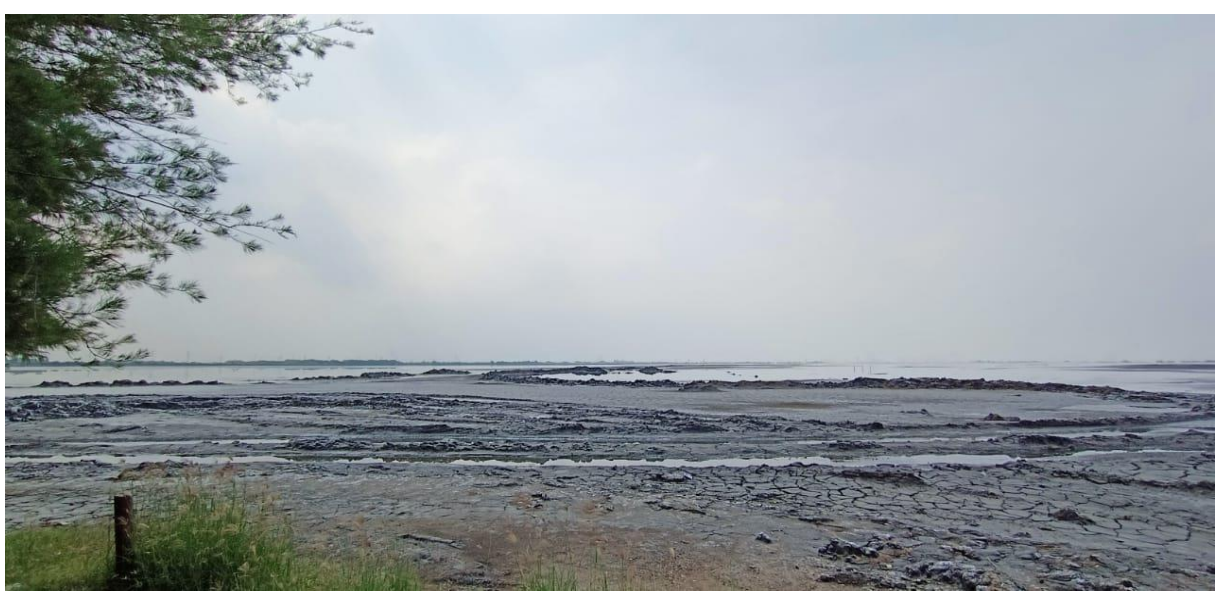

Figure 3. View of Lapindo Mud

Source: Field Documentation During Research

The Lapindo mudflow center is also classified as still active and can pollute the clean water environment in Sidoarjo Regency. Lapindo Mud can be an iconic city of Sidoarjo, so the attraction of this disaster tourism is no longer in doubt. However, in terms of infrastructure development for the comfort and safety of tourists, it is still not guaranteed because the Lapindo Mud tour has not been registered as an official tour and the formation of the Lapindo area into Lapindo Mud dark tourism is only the spontaneity of the local community. In addition, Lapindo Mud dark tourism should build a museum to support Lapindo Mud into historical tourism and educational tourism because the museum can be used to store remnants from the onset of the disaster to the aftermath of the disaster. In this case, there is no stipulation and virtue and a threshold for victims of the Lapindo Mud, just working dangerously back and forth without using it.

\section{E. Conclusion}

The dark tourism opportunity from Lapindo Mud is tourist's motivation, both local and foreign. It is because of sympathy and curiosity, not to admire beauty and vacation so that in terms of tourist attraction, Lapindo Mud is compatible with the theme of dark tourism because it is related to a tragedy and disaster. The challenge of dark tourism from Lapindo Mud is that there is no coordination between the association and the government regarding licensing, tourism management, financial management, and even those responsible for Lapindo Mud dark tourism, even though the Lapindo Mud area is hazardous.

It is hoped that with the potential for dark tourism, the local government can make improvements and development, especially in infrastructure development, as a viable tourist spot that offers experiences such as praying together or watching a film about the disaster. Likewise, local people who can become tour guides are given training so that both local and foreign tourists get more educational information while visiting. Innovation must be made so that 
Dark Tourism Opportunities and Challenges: A case study from Lapindo Mud Disaster

Lapindo Mud dark tourism does not experience a decline. One of the efforts that can be done is with a virtual tour. Virtual tours provide experiences like experiencing and being at a tourist location by watching a screen or monitor. It would be better if the virtual tour is presented in 3D. If the Sidoarjo local government supports the management problems, it will be very beneficial for the region and the victims of Lapindo Mud.

\section{REFERENCES}

Andriani, C. (2011). Dampak Sosial Bencana Lumpur Lapindo dan Penanganannya Di Desa Renokenongo (Studi Tentang Penanganan Ganti Rugi Warga Desa Renokenongo). Thesis. UPN Jatim.

Cresswell, J. W. (2014). Research design pendekatan kualitatif, kuantitatif, dan mixed. Yogyakarta: Pustaka Belajar.

Daulay, P. (2010). Survival Mechanism Victim Houshold Of Lumpur Lapindo In Sidoarjo - Jawa Timur. Jurnal Organisasi Dan Manajemen, 6(1): 74-88.

Dewan. (2011). Ahli Geologi Inggris: Pengeboran Lapindo Penyebab Semburan Lumpur Sidoarjo. Retrieved February 25, 2021, from bttps:/ / www.voaindonesia.com/ a/geolog-inggris-pengeboran-lapindo-penyebabsemburan-lumpur-sidoarjo-122849564/93842.html.

Dirgantara, A. R. (2013). Kajian Dark Tourism Gempa Bumi Sichuan. Pariwisata dan Mitigasi Bencana: 1-20.

Fajerial. (2014). Jokowi Disarankan Ubah Status Bencana Lapindo. Retrieved May 13, 2021, from https:// nasional.tempo.co/read/627821/jokowi-disarank.an-ubahstatus-bencana-lapindo.

Farida, A. (2013). Jalan Panjang Penyelesaian Konflik Kasus Lumpur Lapindo. Jurnal Ilmu Sosial Dan Ilmu Politik, 17: 144-162.

Gupta. (2016). 10 Tabun Lumpur Lapindo, Bencana dan Keberuntungan. Retrieved June 17, 2021, from https: / regional.kompas.com/ read/2016/06/15/15382461/10.tabun.lumpur.lap indo.bencana.dan.keberuntungan?page $=$ all .

Jamin, A., Mohd Zain, Z., Rosnita Sakarji, S., Ahmad, N., \& Mayang Delima Mohd Beta, R. (2020). The Benefits of Dark Tourism Experience among Visitors in Malaysia. KnE Social Sciences: 219-228.

Kriswibowo, A. (2018). Potensi Pembangunan Pariwisata Berbasis Masyarakat di Jawa Timur (Studi Tentang Social Capial Sebagai Sustainable Resources). Dinamika Administrasi : Jurnal Ilmu Administrasi Dan Manajemen, 1(1): 1-14.

Kunwar, R. R., \& Karki, N. (2019). Dark Tourism: Understanding the Concept and Recognizing the Values. Journal of APF Command and Staff College, 2(1): 42-59.

Muktaf, Z. M. (2017). Wisata Bencana: Sebuah Studi Kasus Lava Tour Gunung

Tourism Research Journal, Volume 5 (2), 2021 
Dark Tourism Opportunities and Challenges: A case study from Lapindo Mud Disaster

Merapi. Jurnal Pariwisata, IV(2): 84-93.

Natalija Minić. (2012). Development Of „Dark“ Tourism In The Contemporary Society. Geogr. Inst. Cvijic, 62(3): 81-103.

Pardamean Daulay. (2019). Migrasi Terpaksa Masyarakat Korban Bencana:

Menelusuri Potret Kelangsungan Hidup Korban Lumpur Lapindo di Desa

Kedungsolo Kecamatan Porong Sidoarjo. Talenta Conference Series: Local Wisdom, Social, and Arts (LWSA), 2(1): 1-12.

Kementrian Pariwisata. (2019). Pedoman Pengembangan Wisata Sejarah dan Warisan

Budaya. Gedung Film Pesona Indonesia. Jakarta: Asisten Deputi

Pengembangan Wisata Budaya Deputi Bidang Pengembangan Industri dan Kelembagaan Kementrian Pariwisata.

Rahmawati, R., \& Reni, A. (2019). Development of Spiritual Mental After The Earthquake Tragedy. Trauma Healing Pasca Gempa: 1-7.

Riski, P. (2013). Studi Baru Picu Debat Mengenai Lumpur Lapindo. Retrieved July 18, 2021, from bttps://wnvv.voaindonesia.com/a/studi-baru-picu-debat-mengenailumpur-lapindo/1707291.btml.

Restanto, D., \& Listiyani, R. H. (2013). Konstruksi Sosial Pengunjung Wisata Lumpur Panas Lapindo. Paradigma, 1(3): 1-4.

Suparno. (2016). Tabur Bunga dan Aksi Teatrikal Peringati 10 Tabun Semburan Lumpur Lapindo. Retrieved July 27, 2021, from bttps://news.detik.com/berita-jawatimur/d-3221046/tabur-bunga-dan-aksi-teatrikal-peringati-10-tabun-semburanlumpur-lapindo

Syaraffah, M. (2014). Lumpur Lapindo Meninggi, 110 Patung Tenggelam. Retrieved August 12, 2021, from https:/ / nasional.tempo.co/ read/ 604152/ lumpur-lapindomeninggi-110-patung-tenggelam,

White, L., \& Frew, E. (2013). Dark Tourism and Place Identity: Dark Tourism and Place Identity: London: Routledge Taylor \& Francis Group. 